\title{
On a Level Playing Field? The Effect of Parents' Education on Master's Degree Graduates' Labour Market Success in Finland
}

\author{
Ulpukka Isopahkala-Bouret* ${ }^{*}$, Hanna Nori ${ }^{(1)}$ \\ Department of Education, University of Turku, Turku, Finland \\ Email: *ulpukka.isopahkala-bouret@utu.fi
}

How to cite this paper: Isopahkala-Bouret, U., \& Nori, H. (2021). On a Level Playing Field? The Effect of Parents' Education on Master's Degree Graduates' Labour Market Success in Finland. Advances in Applied Sociology, 11, 626-643.

https://doi.org/10.4236/aasoci.2021.1112053

Received: October 19, 2021

Accepted: December 21, 2021

Published: December 24, 2021

Copyright (c) 2021 by author(s) and Scientific Research Publishing Inc. This work is licensed under the Creative Commons Attribution International License (CC BY 4.0).

http://creativecommons.org/licenses/by/4.0/

\begin{abstract}
It is usually assumed that graduates with similar degrees are on a level playing field in the labour market. However, this common perception conceals social differences among the highly educated population. Following Bourdieu's thesis that those with a privileged background benefit most from their degreed education due to the effects of inheritance of cultural capital, we investigate whether parents' education affects Master's degree graduates' success in the Finnish labour market. We use nationally representative data of Finnish 25 45-year-old graduates from a broad educational field of business administration and social sciences $(\mathrm{N}=7798)$. The results show that graduates whose parents have not attained post-compulsory education have lower success rates in the labour market than other graduates. However, graduates whose parents have attained higher education have similar success rates as graduates whose parents have attained upper secondary education. In addition, the effect of parents' education diminishes with graduates' age and career progression. Our findings provide new knowledge to policymakers, university administrations, and employers interested in graduate employability and social inequality. It is suggested that further research, targeted measures and career support are needed to ensure that graduates coming from low-educated families can have equally successful entry to the labour market.
\end{abstract}

\section{Keywords}

Higher Education, Master's Degree, Labour Market Success, Parents' Education, Cultural Capital

\section{Introduction}

Graduates' opportunities to gain equal benefits from their university education 
in the labour market and the way their parents' educational level affects these opportunities are examined in this study. Once a graduate has achieved a degree, it is taken for granted that, from then on, they are members of the highly educated middle class and are on a level playing field with all graduates holding the same kind of degree (e.g., Torche, 2011). Ford (2018) summarised how the dominating sociological tradition of "status attainment" has supported this common understanding of the relationship between social origins, educational attainment, and occupational destinations in numerous empirical studies ${ }^{1}$. After all, educational degrees are intended to guarantee that graduates of the same educational level and field have generally acquired similar abilities and skills; thus, they can compete for labour market success on equal footing, regardless of their family background and parents' education. This reflects a belief in meritocracy, which is deeply rooted in Western societies.

Nevertheless, the common perception that all university graduates are of equal standing in the labour market conceals social differences among the highly educated population. Prior research has recognised that, in particular, graduates coming from a low social background can face difficulties in transitioning to good quality employment (e.g., Ashley \& Empson, 2013, 2017; Bathmaker et al., 2013; Boliver, 2017; Christie, 2019; Ford, 2018; Hurst, 2018; Lehmann, 2019). To explain how parents' education conditions graduates' labour market transitions, scholars have applied Bourdieu's conceptual framework. Bourdieu (1984) developed an argument in Distinction that the full benefit of an education can only be reaped by those graduates with a privileged social background due to the fact that they have "inherited" sufficient cultural capital, such as certain personal traits, knowledge and skills. Furthermore, they know how to "play the game" (Bathmaker et al., 2013) and convert acquired cultural capital to labour market success (Hurst, 2018). Graduates' labour market success is here defined as an accomplishment of a high socioeconomic status and high income.

In this study, we are interested in investigating whether the claimed importance of inherited cultural capital is reflected in Finnish graduates' labour market success in the twenty-first century. Finland, as a Nordic welfare state, has demonstrated strong political commitment to the equality of education ${ }^{2}$, including equal opportunities to access higher education (e.g., Finnish Government, 2019). With the expansion of higher education, students have increasingly diverse social backgrounds. A considerable share of students come from non-academic family backgrounds and, thus, the opportunity gap in access to higher education has diminished between students whose parents have a university degree and

${ }^{1}$ To learn more about recent comparative and critical studies on status attainment theory, see, for example, Bernardi and Ballarino (2016).

${ }^{2}$ It should be noted that while the terms equality and equity are often used synonymously, equality refers to similar or even identical treatment and is assessed quantitatively, while equity tends to mean just and fair treatment, which does not always need to be identical to the treatment of others (Espinoza, 2007: pp. 345-346). Equality is the more appropriate concept for this article, as graduates who have completed an equivalent educational degree can be expected to achieve similar or identical labour market outcomes. 
those whose parents have not attained higher education (Kivinen et al., 2012; Isopahkala-Bouret et al., 2018; Kohvakka et al., 2019; Nori, Juusola, Kohtamäki, Lyytinen, \& Kivistö, 2021). Far less attention has been paid to what happens after graduation.

The purpose of this study is to investigate empirically whether parents' education matters in successful labour market positioning after graduation. We use large-scale, register-based data on Finnish university Master's degree graduates from one broad "educational field": business administration and social sciences $(\mathrm{N}=7798)$. Business administration and social sciences are socially selective study fields in Finland. For example, in 2016, 28 percent of applicants had father and 27 percent mother who had completed Master's or Doctor's degree, with the corresponding proportions of those admitted being 33 percent and 32 percent (Nori et al., 2021). In recent years, the proportion of women in this field has been about 60 percent, which corresponds to the gender distribution of the entire university education (Nori et al., 2021). Linear regression is used to examine the effect of parents' education on graduates' labour market success.

Regarding the organisation of this article, we begin by contextualising our study within the field of research on the equality of higher education in Finland. Second, we examine how family background may affect labour market success after graduation using Bourdieu's theoretical concepts. Third, we explain the research questions, hypotheses, and methods. Fourth, we present our empirical findings. Finally, we discuss the implications of these results and further research needs.

\section{The Equality of Higher Education in Finland}

Finland and the other Nordic countries are often considered to be egalitarian by international standards. Social differences are relatively small, which can be attributed to welfare and labour market policies, as well as education. The perceived egalitarianism is grounded on the following three fundamental qualities of its educational system, which are also typical of the other Nordic countries:

1) Various routes to university; no "dead ends" in the educational system.

2) No tuition fees; a universal student allowance system.

3) Small status differences between universities.

First, Finland has a comprehensive education system, and selection takes place quite late in adolescence, at 15 - 16 years old. Thus, everyone follows the same curriculum for the first nine years of education. Even after division into general and vocational upper secondary education, all students have eligibility to apply for higher education (Nylund et al., 2018). Second, in the Nordic countries, the direct effect of parents' monetary resources is considerably smaller than in countries with more market-driven educational systems. There are no tuition fees for higher education in Finland. Student meals, health care, and housing are heavily subsidised by the state. Finland has also a universal student allowance ${ }^{3}$ Due to data protection legislation, the classification of "educational fields" in the data provided by Statistics Finland is coarse and combines several fields of education. 
system, which lowers the financial barrier to study at a university (Social Insurance Institution Finland, 2018). Thirdly, the institutional and social stratification between universities is rather small in Finland and other Nordic countries, there are no elite universities, and, thus, socioeconomic inequalities are mostly visible between fields of study rather than between universities (Isopahkala-Bouret et al., 2018; Thomsen, Bertilsson, Dalberg, Hedman, \& Helland, 2017).

However, even in Nordic countries, social background does affect the path to/through higher education. In specific relation to university education in Finland, we distinguish the following phases, each of which can be affected by social background:

1) Application \& admission.

2) University studies.

3) Graduation.

Application and admittance percentages to university show clear differences regarding parental background (Kivinen \& Hedman, 2016; Nevala \& Nori, 2017; Nori et al., 2021). The children of fathers with high social background are grossly over-represented among university applicants, whereas the children of fathers with low social background are under-represented in comparison to the distribution of social background in the general population (Kohvakka et al., 2019) ${ }^{4}$. Applicants from privileged backgrounds typically choose highly selective, high-status disciplines, whereas those from lower social backgrounds typically apply to less selective and more vocationally orientated programmes (Nori et al., 2021).

Parental wealth also helps students to get by during their studies. Wealthy parents may assist their child financially or even buy an apartment for the child to use during their studies, thereby removing or minimising accommodation expenses. Working-class students receive less financial support from their parents or relatives than middle-class students and are more likely to need to work during studies or to have financial difficulties that affect their studies (Mikkonen \& Korhonen, 2018: pp. 24-25). Social background affects also academic success at university; students from more privileged parental backgrounds generally achieve better grades (c.f., Hansen \& Mastekaasa, 2006). However, the extent to which academic grades affect success in the labour market is disputable. Previous Finnish research (Aho, Hynninen, Karhunen, \& Vanttaja, 2012) has shown that academic success may even affect employability in an opposite direction to that expected, whereby those with the best academic results achieve below-average ${ }^{4}$ Until 2019, an entrance examination had been required to gain entry to university in Finland, and preparation courses were often required to succeed in the entrance examination, especially in high-status educational fields, such as business, law and medicine. As these preparation courses were expensive, parental wealth obviously increased the possibility of gaining entrance to such courses and, therefore, indirectly improved the applicant's chances of being accepted to university (Kosunen \& Haltia, 2018). While this article was written, the student selection to Finnish universities was reformed, and since 2020 the majority of students have been selected on the basis of their matriculation examination. The reform has diminished the role of entry examinations and preparation courses. On the other hand, private courses that prepare for matriculation test are now offered to upper secondary school students. 
success in the labour market.

There is no clear link between parents' educational background and the graduation rate in Finland. In 2017, a higher proportion (52\%) of the children of parents with lower secondary education or less completed their studies on time than the children of highly educated parents (41\%) (OECD, 2019). There are no available statistical studies on the connection between dropping out of higher education and family background in Finland; this is partly because those who started their studies before 2005 were granted study rights for an unlimited time. Therefore, even if they have not made any progress in their studies for years, they have not officially dropped out. In other countries, prior studies have shown that students from low socioeconomic backgrounds have the highest risk of drop-out (Thomas \& Quinn, 2007).

\section{Parents' Education and the Inheritance of Cultural Capital}

Bourdieu $(1984 ; 1986)$ has introduced an influential conception of three forms of capital: social, cultural, and economic capital. People with different family backgrounds differ from one another with regard to their possession of such capitals. Scholars in sociology of education have been especially interested in the accumulation of cultural capital. In this study, we are interested in parents' education, which we associate with cultural capital that university graduates have "inherited" from their childhood families. Parents' educational degrees are indicators of institutionalised cultural capital.

Bourdieu $(1984,1986)$ considers graduates' inherited cultural capital to be embodied; it consists of deeply personal characteristics such as style of speech and manners. Inherited cultural capital is mostly based on family background and is slowly accumulated over time. According to Bourdieu (1986), "marks" of inherited cultural capital, such as pronunciations characteristic of a class or region, can reveal whether graduates' underlying social background is lower than that suggested by their educational degree, even if it is camouflaged by a layer of institutionalised cultural capital acquired through higher education.

We focus in this study on cultural capital, but it is noteworthy that cultural capital is connected and convertible with economic and social capitals. Bourdieu (1986) regards economic capital as the most readily convertible form of capital. The "conversion rates" between the different forms of capital vary and depend on the field in question, such as a specific occupation or profession. Each field requires a different set of capitals, and this is reflected in the characteristics and behaviour that are valued in that field (Bourdieu, 1986). The conversion of capital is bidirectional according to Bourdieu (1984). On the one hand, economic capital can be converted into institutionalised cultural capital, i.e., educational degrees, which legitimise differences in socio-economic background by making them seem natural and objective. In this process, the family origins and other social differences are concealed. Bourdieu (1991) calls this process "social magic". On the other hand, upon graduation, the objective is usually to convert 
educationally acquired cultural capital into economic capital, that is, success in the labour market.

Bourdieu (1984) argues that the rate of converting educational achievements into success in the labour market depends on graduates' amount of inherited cultural capital; graduates with a priviledged family background benefit most from their degreed education:

Outside of a specifically scholastic market, a diploma is worth what its holder is worth, economically and socially, the rate of return on educational capital is a function of the economic and social capital that can be devoted to exploiting it. (Bourdieu, 1984: p. 134)

This is not to say that those with low-educated parents do not benefit from a high level of education. Attaining a degree certainly helps graduates from a disadvantaged background to be more successful than they would be with less formal education or a lower status education. In that sense, education does pay off. Arguably then, more education or a higher level of education is always better for an individual at any point in time, as formal education is an important symbol of cultural capital. However, according to Bourdieu (1984), graduates in high-status educational fields who originate from low social backgrounds are more likely to be employed in lower-tier firms and organisations than in elite ones (p. 50) .

The advantage of graduates with a high social background and highly educated parents has been indicated in recent empirical research. Parents have expectations that influence graduates' career aspirations (Loewenthal et al., 2019), and employers may screen applicants based on their social background. For example, Tholen et al. (2013), Rivera (2011, 2012), and Binder et al. (2016) demonstrated how elite employers, especially in finance, consulting, and high technology, and highly selective, private universities co-align and pave the way for the career success of graduates with privileged social backgrounds. Ashley and Empson (2013), for example, found that only one of the top law firms that participated in their study hired employees from a relatively diverse range of social backgrounds. This firm had the lowest profit per equity partner among all the firms in the study (p. 233). All the other leading law firms were more exclusive in terms of their recruits' social backgrounds.

Graduates with a low social background may have a harder time proving their value to employers, even if their skills are equal. This is manifested in the recruitment decisions of leading law, accounting, investment banking, and consulting firms, as discussed in the above-mentioned studies. A high level of embodied cultural capital signals a "fit" with both existing employees and the predominantly upper-class clientele of these industries, a factor that often overrides other merits and talent (Ashley \& Empson, 2013; Binder et al., 2016; Rivera,

${ }^{5}$ Recently, Forster et al. (2021) explained that returns on higher education are rather homogenous, which means that all students gain equal relative benefits from a university degree (in terms of their wage premium). However, students from an advantaged background still receive higher absolute wages than those from low social origins. 
2012). Applicants must prove their worth to an employer usually in a job interview, which is, in practice, more a demonstration of cultural capital than of skills.

Parents influence both career expectations and preparedness for entering the labour market. Bathmaker et al. (2013) (see also Bowers-Brown et al., 2017; Burke et al., 2020) explored the effects of graduates' family background by applying and expanding on Bourdieu's concepts. They showed that graduates with middle-class backgrounds have more cultural capital to "add value" to their education. For example, they can engage more in hobbies and other activities than graduates with working-class backgrounds as a means of standing out from their peers in the labour market (see also Burke et al., 2020; Hurst, 2018).

Moreover, parental economic and social capital impacts the conversion of cultural capital to desired outcomes in the labour market (e.g., Hurst, 2018). Parents particularly facilitate finding a first job. Highly educated parents have better social connections and can help students obtain prestigious internship positions (Allen et al., 2013; Bathmaker et al., 2013; Tholen et al., 2013). The effect of family background on graduates' labour market transitions has been studied mostly in higher education systems where students pay high fees; more research is needed on higher education systems with low or no admission fees, such as that in Finland (Isopahkala-Bouret et al., 2018).

Previous studies show that the effect of parents' education may diminish with age of graduates (Jacob, Klein, \& Iannelli, 2015; Nori, Peura, \& Jauhiainen, 2020). Furthermore, according to Hansen (2001), those who have survived higher education selection processes despite a low-educated family background, should have an ability and willingness to succeed in their career. We may also assume that graduates with degrees in business and social sciences, as particularly selective fields in Finland, are a very competent group of people. Next, we will analyse whether the differences of parents' education affect labour market success after graduation in Finland, as one might expect from a Bourdieuan perspective.

\section{Research Design}

\subsection{Research Task and Main Hypotheses}

Following Bourdieu's thesis that graduates with a privileged background benefit more from their degreed education due to the effects of inherited cultural capital, we investigate whether parents' education affect Master's degree graduates' success in the Finnish labour market. Our research task can be summarised in the following two hypotheses:

H1: Graduates with highly educated parents succeed better in the labour market, they gain higher socioeconomic status and income than graduates with low-educated parents.

H2: The effect of parents education is highest at the entry to the labour market and it diminishes with older age and career progression.

The business administration and social sciences were selected to this study 
because they are generalist fields and open up various job opportunities. In such generic fields, university degrees are not used as a mechanism of closure, which involves restricting access to professions and occupations on the basis of specific educational requirements; a degree is rather understood as a signal of (potential) capability for high performance (see: Isopahkala-Bouret et al., 2021; Tholen 2020). Bourdieu (1984) has argued that the effect of parental background and inherited cultural capital on the realisation of labour market success is most evident in those occupational fields, which do not require specific technical expertise but in which being recognised as an expert is tied to personal characteristics. It can, thus, be assumed that the effect of parents' education is greater in the generalist fields such as business administration and social sciences that in some closed professions.

\subsection{Data and Methods}

The data used in this study is from a register-based 5 percent cross-cut sample of Finnish 25 - 45 year old graduates from 2010 to 2012 (pooled together) from the "educational field" of business administration and social sciences. The data set was provided by Statistics Finland and it contained 7798 cases. Table 1 shows how the data is divided according to background characteristics.

Table 1. Frequencies of the independent variables.

\begin{tabular}{|c|c|}
\hline & Bus/Soc \\
\hline \multicolumn{2}{|l|}{ Gender } \\
\hline Male & 3014 \\
\hline Female & 4784 \\
\hline \multicolumn{2}{|l|}{ Age group } \\
\hline $25-29$ & 1353 \\
\hline $30-34$ & 2183 \\
\hline $35-39$ & 2017 \\
\hline $40-45$ & 2245 \\
\hline \multicolumn{2}{|c|}{ Parents' education index } \\
\hline 2 (lowest) & 1303 \\
\hline 3 & 1067 \\
\hline 4 & 1284 \\
\hline 5 & 941 \\
\hline 6 & 988 \\
\hline 7 & 548 \\
\hline 8 & 678 \\
\hline 9 & 339 \\
\hline 10 (highest) & 650 \\
\hline Total & 7798 \\
\hline
\end{tabular}


The main independent variable was parents' education, which was operationalised using an index that combines both parents' level of formal education. The categories and values of the variables used to measure parents' educational levels were as follows: compulsory education or less (1), upper secondary education (2), lowest tertiary level (3), Bachelor's degree level (4), and Master's degree level and above (5). The educational levels of fathers and mothers combined resulted in a scale of 2 - 10, the aim being to measure the cultural capital "inherited" from the graduates' childhood family.

In addition, we used age (continuous) and gender as control variables. We grouped age in five-year intervals beginning with the $25-29$ group and ending with the 40 - 45 group. Gender refers here to whether a person is male or not, and it was included in the analysis as a dummy variable (male $=1 / 0)$.

We constructed an index of labour market success (LMS) by combining the dimensions of graduates' socioeconomic status and income. The LMS index measured how graduates with different social background have been able to realise the benefits of their degreed education (c.f., conversion of cultural capital to economic and social capitals; Bourdieu, 1986).

The socioeconomic status and income variables, both of which take a value ranging from 1 to 5, were summed to form an index with a range of 2 - 10 (see Table 2). Socioeconomic status was classified according to the 1989 classification of Statistics Finland (https://www.stat.fi/fi/luokitukset/sosioekon_asema), except that we did not include the category of entrepreneurs ${ }^{6}$. For income, we examined wage quartiles, calculated based on gross wages among graduates separately for each year. Entrepreneur income was not included.

By using regression analysis, we wanted to analyse which factors explain labour market success (a dependent variable) and to what extent. In this way, we were also able to detect the effect of age and gender on the variable to be explained.

First, we examined the means of the index measuring the labour market success in the categories of the index of parents' education descriptively. Second, we ran three models of linear regression analysis adding one independent variable (parents, gender, and age) at each step.

Table 2. Labour market success: construction of the index (scale: 2 - 10).

\begin{tabular}{cc}
\hline Socioeconomic status & Income level \\
\hline 1 Unemployed/outside workforce & 1 No wage income \\
2 Clerk/worker & 2 Lowest wage quartile \\
3 Associate professional & 3 Second wage quartile \\
4 Professional & 4 Third wage quartile \\
5 Leading professional & 5 Highest wage quartile \\
\hline
\end{tabular}

${ }^{6}$ The status of being an etrepreneurer does not indicate hierarchical social position in a similar ways as the other socioeconomic status categories; some individuals who are classified as entrepreneurs may run a large international firms and some are self-employed professionals. 


\subsection{Limitations}

Our focus is solely with parental education in our study. We acknowledge that to determine family background (socio-economic background or social class), there are other potentially important measures, such as parental occupation and income. However, in our data there is no measure of parents' occupational status or family wealth. In earlier studies, parental education has been commonly used as the sole measurement of university students' and graduates' social background (e.g., Ford, 2018; Kivinen, Hedman, \& Kaipainen, 2012). Furthermore, when studying selection to Finnish universities, Kohvakka et al. (2019: p. 49) found that the effect of family background is manifested mainly through parents' education instead of parents' socio-economic status or income.

\section{Analysis}

\subsection{Graduates with Low-Educated Parents Are Disadvantaged}

We began by examining the means of the labour market success index (LMS index) in relation to parents' education (Figure 1 and Figure 2). The clearest visual finding is that graduates with the lowest level of parental education (both parents educated only at the compulsory level or less) differ distinctly from the rest of the graduates. This result was confirmed among male and female graduates, and in all age groups.

Moreover, our analysis shows that when parental education exceeds post-compulsory level, it does not differentiate graduates' opportunities for labour market success. This means that graduates whose parents have attained higher education have similar rates of labour market success as graduates whose parents have attained upper secondary level of education. Therefore, these findings support only partially our first hypothesis that higher family background is associated with better success in the labour market.

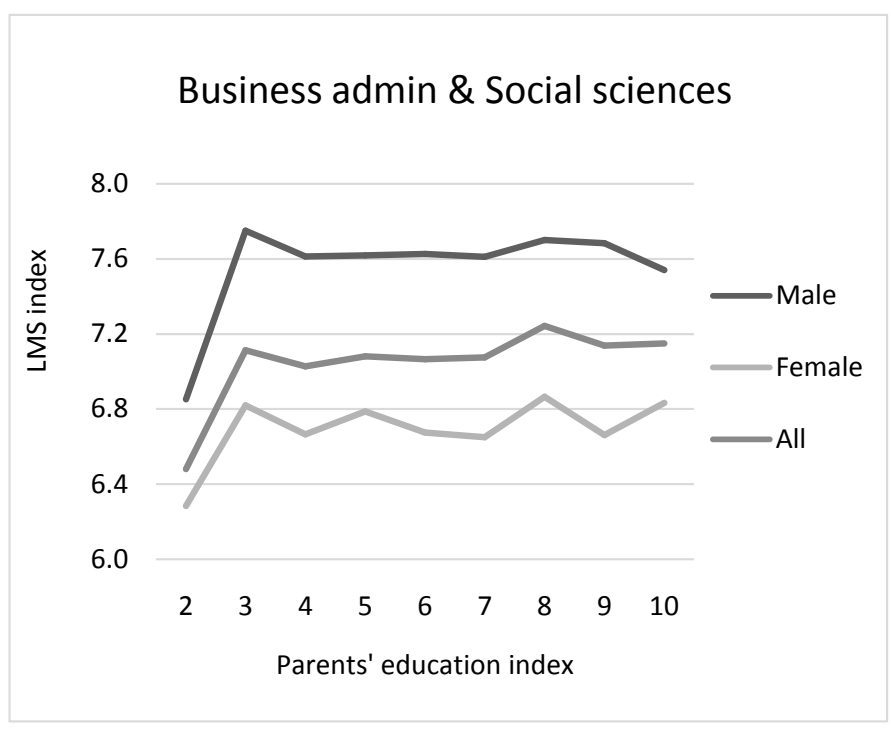

Figure 1. Means of the Labour market success (LMS) index (scale 2 - 10) in relation to parents' education and gender. 


\section{Business admin \& Social sciences}

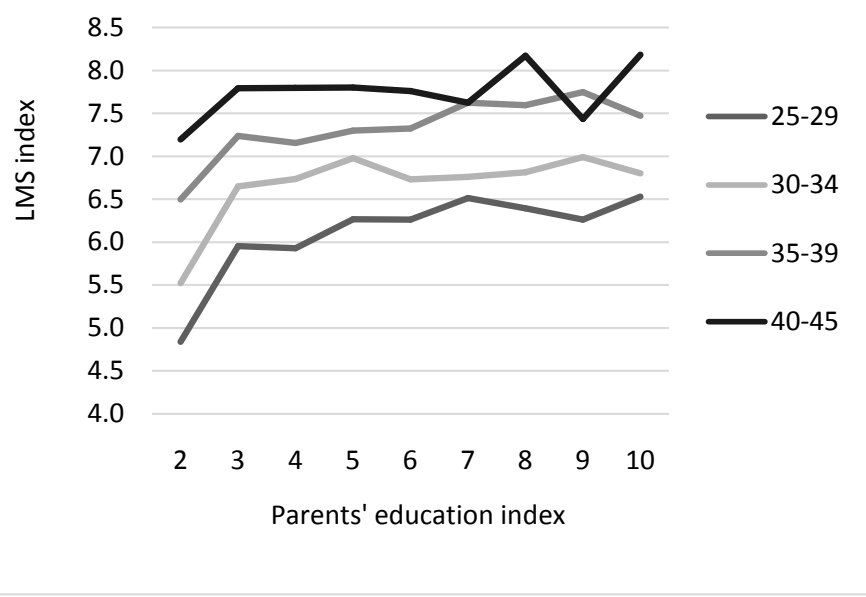

Figure 2. Means of the Labour market success (LMS) index (scale 2 - 10) in relation to parents' education and age category.

Furthermore, the differences between male and female (Figure 1) and age groups (Figure 2) were considerable.

In the linear regression (Table 3), we concentrated on parents' education (Parents) as the main independent variable, while controlling for gender (categorical dummy) and age (continuous). We ran three models adding one independent variable at each step.

The beta values for parents' education (Parents) are statistically significant ( $p$ $<0.001$ ) in all cases (the very first model in Table 3). However, the relative weight of parents' education is considerably smaller than that of gender and smaller again than that of age, based on the standardised beta values.

\subsection{Biggest Differences at Young Age and at the Entry to the Labour Market}

Our second hypothesis that the effect of parents educational background is strongest in the youngest age group and clearly diminishes with age and career progression was supported. As a visual inspection of the results showed that the effect of parents' education seemed to differ in the youngest age category (25 - 29 years, see Figure 2), we ran a separate round of analyses for this age category (Table 4). In this age category, the regression coefficients for parents' education are clearly higher than in Table 3, the standardised beta being roughly as high (or higher) for parents' education as for the control variables.

The R squared values are low for all the models (Table 5), the highest being 0.115 (approx. 12\%). The effect of parents' education clearly peaked being almost 20 percent at the very beginning of ones' career.

\section{Discussion}

Finnish higher education system consists of globally unique features such as 
Table 3. Linear regression.

\begin{tabular}{|c|c|c|c|c|c|c|c|}
\hline & & $\beta$ & $\begin{array}{l}\text { Std. } \\
\text { Error }\end{array}$ & $\begin{array}{c}\text { Stand. } \\
\text { Beta }\end{array}$ & Sig. & $\begin{array}{r}95 \% \text { C } \\
\text { Lower }\end{array}$ & $\begin{array}{l}\text { nf. Int. } \\
\text { Upper }\end{array}$ \\
\hline Bus/Soc Model 1 & Parents & 0.064 & 0.010 & 0.075 & 0.000 & 0.045 & 0.083 \\
\hline \multirow{2}{*}{ Model 2} & Parents & 0.114 & 0.010 & 0.133 & 0.000 & 0.096 & 0.133 \\
\hline & Age & 0.112 & 0.004 & 0.292 & 0.000 & 0.103 & 0.120 \\
\hline \multirow{3}{*}{ Model 3} & Parents & 0.099 & 0.009 & 0.116 & 0.000 & 0.080 & 0.118 \\
\hline & Age & 0.106 & 0.004 & 0.277 & 0.000 & 0.097 & 0.114 \\
\hline & Gender (Male) & 0.726 & 0.047 & 0.166 & 0.000 & 0.633 & 0.819 \\
\hline
\end{tabular}

Table 4. Linear regression, age group 25 - 29.

\begin{tabular}{|c|c|c|c|c|c|c|c|}
\hline & & $\beta$ & $\begin{array}{l}\text { Std. } \\
\text { Error }\end{array}$ & $\begin{array}{c}\text { Stand. } \\
\text { Beta }\end{array}$ & Sig. & $\begin{array}{l}95 \% \text { C } \\
\text { Lower }\end{array}$ & $\begin{array}{l}\text { nf. Int. } \\
\text { Upper }\end{array}$ \\
\hline Bus/Soc Model 1 & Parents & 0.145 & 0.021 & 0.190 & 0.000 & 0.104 & 0.185 \\
\hline \multirow{2}{*}{ Model 2} & Parents & 0.154 & 0.020 & 0.202 & 0.000 & 0.114 & 0.193 \\
\hline & Age & 0.301 & 0.039 & 0.205 & 0.000 & 0.225 & 0.378 \\
\hline \multirow{3}{*}{ Model 3} & Parents & 0.148 & 0.020 & 0.195 & 0.000 & 0.109 & 0.188 \\
\hline & Age & 0.291 & 0.039 & 0.198 & 0.000 & 0.214 & 0.368 \\
\hline & Gender (Male) & 0.334 & 0.106 & 0.084 & 0.002 & 0.541 & 0.987 \\
\hline
\end{tabular}

Table 5. R squared for the regression models.

\begin{tabular}{cccc}
\hline & Model & All & $25-29$ \\
\hline Bus/Soc & 1 & 0.006 & 0.036 \\
& 2 & 0.088 & 0.078 \\
& 3 & 0.115 & 0.085 \\
\hline
\end{tabular}

largely public funding and absence of tuition fees; and there is a strong egalitarian ideology behind it. Although not commonly acknowledged, the Finnish systems also have social bias in access to and outcomes of higher education (Isopahkala-Bouret et al., 2018). An important question in terms of equality of education is the opportunity gap in graduate employability, i.e., why certain social groups have lower success rate in entry to graduate jobs?

In this study we investigated the effects of parents' education on the Finnish Master's degree graduates' labour market success in the field of business administration and social sciences. The results show that graduates whose parents had no post-compulsory education differed from the rest distinctively and they were disadvantaged at the entry to the labour market. This result aligns with our first hypothesis. The graduates with the lowest parental background were employed in lower occupational positions and had lower income than other graduates. In these cases, neither parent could compensate for the other parents' low educational level, nor the family's overall cultural capital during the child's upbringing 
remained low.

Moreover, parents' having at least upper secondary qualifications, or vocational diploma, has an equalising effect on graduates' opportunities. Graduates whose parents had a higher education degree did not differ from those whose parents had a vocational degree. Such limited impact of parents' education after parents exceed post-compulsory level may be explained by the characteristics of Finnish education system (see the section on the equality of higher education in Finland). Moreover, the university Master's degree graduates have already demonstrated suitable cultural capital during the competitive university admission processes. At the university, they have adapted to the academic community and to the lifestyle of students. In addition, as stratification between Finnish universities is relatively small (Isopahkala-Bouret et al., 2018), institutional differences do not influence graduates' acquired cultural capital. In addition, the limited impact of parents' education can be partly explained by the quality of the Finnish labour market. Finland is a Nordic welfare state with relatively small income differences (e.g., International Labour Organization, 2016). Moreover, Finnish trade unions are very effective in regulating the labour market, and the vast majority of Finns are members of trade unions. This could be an equalising factor in opportunities after graduation.

While the results supported our first hypothesis only partially, our second hypothesis gained robust support. Parents' educational background made a difference in labour market success in relation to age. The largest effect was found in the youngest age group, who were in the early career phase, and the parents' influence diminished with older age and career progression. Graduates who have progressed in a career have been embedded in the culture of the occupational field in question. Self-acquired cultural capital accumulates during a career and it can compensate for low parental education and a lack of inherited cultural capital.

We used nationally representative, register-based data that enabled high quality of analysis. However, there are two major limitations in this study that could be addressed in future research. First, due to data protection legislation, the classification of the educational fields in the data was coarse. Our selected field of business administration and social sciences combined several smaller disciplinary fields. In the future research, it would be interesting to conduct more targeted, field specific analysis and comparisons between different fields. Second, in our data, there was no measure of parents' socio-economic status or income. In the future research, it would be useful to make a parallel investigation on the effects of parents' socio-economic status and family wealth.

Furthermore, with quantitative methods it is not possible to explore what strategies graduates with low-educated parents use to enter the labour market and why they are occupying less successful positions, at least in an early career. Qualitative research that specifically examines how the effect of family background is experienced by the graduates in egalitarian countries, like Finland, would be beneficial to our understanding of the matter. We have continued our 
own investigations in that direction and conducted over 70 graduate interviews (Haltia, Isopahkala-Bouret, \& Mutanen, under review). Finland, as well as other Nordic welfare states, has a specific educational system and labour market structures and regulations, and it would be interesting to know more on how graduates from different family backgrounds navigate in this landscape. Furthermore, there is a need to deepen our understanding with qualitative study on how gender interrelates with family background and affects graduates labour market success.

This study provides new knowledge to policymakers, university administrations, and employers interested in graduate employability and social inequality. Our findings have confirmed, contrary to a common assumption, that low-level parental education affect entry to Finnish labour market. While equal outcomes of education cannot be set as a general goal in society, because abilities and efforts vary between individuals, it can be inferred that family background should not impact labour market success among people with equivalent educational credentials.

It is suggested that practical measures and support structures would be implemented to reduce inequalities between graduates. As Burke et al. (2020) have stated, also targeted career support and counselling is needed to ensure that graduates coming from low-educated families can have equally successful entry to the graduate labour market. In addition, fairly distributed and paid internships and work practices during studies could facilitate the labour market entry of graduates with less inherited cultural capital. This study provides hope that once the fairness of access to entry-level positions is improved, parents' education does not have an enduring effect on graduates who are older and have progressed in their career.

\section{Funding}

This work was supported by the Academy of Finland under Grant 315797.

\section{Biographical Notes}

Ulpukka Isopahkala-Bouret works as a Professor at University of Turku. Her research interest includes equality in/through higher education, educational credentialing, and access to higher education. Moreover, she is currently leading a project on graduates' employability and early career trajectories. She is also the chief editor of Aikuiskasvatus, a peer-reviewed adult education journal.

Hanna Nori works as a University Researcher at University of Turku. She is particularly interested in the accessibility and equality of higher education, selection for postgraduate studies, study experiences of doctoral students, and social divisions and fragmentation of university education.

\section{Acknowledgements}

We would like to acknowledge Dr. Mikko Aro for his contribution for the pre- 
liminary analysis. We would also like to thank the anonymous reviewers for their valuable feedback. Finally, funding from the Academy of Finland (grant number 315797) is gratefully acknowledged.

\section{Conflicts of Interest}

The authors declare no conflicts of interest regarding the publication of this paper.

\section{References}

Aho, S., Hynninen, S.-M., Karhunen, H., \& Vanttaja, M. (2012). Opiskelunaikainen työssäkäynti ja sen vaikutukset [Student Employment and Its Impacts]. Työja elinkeinoministeriö.

Allen, K., Quinn, J., Hollingworth, S., \& Rose, A. (2013). Becoming Employable Students and 'Ideal' Creative Workers: Exclusion and Inequality in Higher education Work Placements. British Journal of Sociology of Education, 34, 431-452.

https://doi.org/10.1080/01425692.2012.714249

Ashley, L., \& Empson, L. (2013). Differentiation and Discrimination: Understanding Social Class and Social Exclusion in Leading Law Firms. Human Relations, 66, 219-244. https://doi.org/10.1177/0018726712455833

Ashley, L., \& Empson, L. (2017). Understanding Social Exclusion in Elite Professional Service Firms: Field Level Dynamics and the 'Professional Project'. Work, Employment and Society, 31, 211-229. https://doi.org/10.1177/0950017015621480

Bathmaker, A.-M., Ingram, N., \& Waller, R. (2013). Higher Education, Social Class and the Mobilisation of Capitals: Recognising and Playing the Game. British Journal of Sociology of Education, 34, 723-743. https://doi.org/10.1080/01425692.2013.816041

Bernardi, F., \& Ballarino, G. (2016). Education, Occupation and Social Origin: A Comparative Analysis of the Transmission of Socio-Economic Inequalities. Edvard Elgar Publishing.

Binder, A., Davis, D., \& Bloom, N. (2016). Career Funneling: How Elite Students Learn to Define and Desire 'Prestigious' Jobs. Sociology of Education, 89, 20-39.

https://doi.org/10.1177/0038040715610883

Boliver, V. (2017). Misplaced Optimism: How Higher Education Reproduces Rather than Reduces Social Inequality. British Journal of Sociology of Education, 38, 423-432. https://doi.org/10.1080/01425692.2017.1281648

Bourdieu, P. (1984). Distinction: A Social Critique of the Judgement of Taste. Harvard University Press.

Bourdieu, P. (1986). The Forms of Capital. In J. G. Richardson (Ed.), Handbook of Theory and Research for the Sociology of Education (pp. 241-258). Greenwood Press.

Bourdieu, P. (1991). Language and Symbolic Power (J. B. Thompson, Ed.). Harvard University Press.

Bowers-Brown, T., Stahl, G., Lacey, S., Morrison, A., Stahl, G., Lacey, S., Morrison, A., \& Stahl, G. (2017). Higher Education, Social Class and Social Mobility: The Degree Generation. International Studies in Sociology of Education, 26, 326-334. https://doi.org/10.1080/09620214.2017.1359230

Burke, C., Scurry, T., \& Blenkinsopp, J. (2020). Navigating the Graduate Labour Market: The Impact of Social Class on Student Understandings of Graduate Careers and the Graduate Labour Market. Studies in Higher Education, 45, 1711-1722. 
https://doi.org/10.1080/03075079.2019.1702014

Christie, F. (2019). Competing Voices: A Figured Worlds Approach to Theorising Graduate Perspectives on Career Success. International Studies in Sociology of Education, 28, 326-344. https://doi.org/10.1080/09620214.2019.1631206

Espinoza, O. (2007). Solving the Equity-Equality Conceptual Dilemma: A New Model for Analysis of the Educational Process. Educational Research, 49, 343-363. https://doi.org/10.1080/00131880701717198

Finnish Government (2019, November 12). Programme of Prime Minister Sanna Marin's Government 10 December 2019. Inclusive and Competent Finland-A Socially, Economically and Ecologically Sustainable Society. http://urn.fi/URN:ISBN:978-952-287-811-3

Ford, K. (2018). Persisting Gaps: Labor Market Outcomes and Numeracy Skill Levels of First-Generation and Multi-Generation College Graduates in the United States. Research in Social Stratification and Mobility, 56, 21-27. https://doi.org/10.1016/j.rssm.2018.06.003

Forster, A. G., van de Werfhorst, H. G., \& Leopold, T. (2021). Who Benefits Most from College? Dimensions of Selection and Heterogeneous Returns to Higher Education in the United States and the Netherlands. Research in Social Stratification and Mobility, 73, Article ID: 100607. https://doi.org/10.1016/j.rssm.2021.100607

Haltia, N., Isopahkala-Bouret, U., \& Mutanen, H. (under review). Getting a Head Start: Inheritance of Capitals and the Labour Market Entry of Finnish Business Graduates.

Hansen, M. (2001). Education and Economic Rewards. Variations by Social-Class Origin and Income Measures. European Sociological Review, 17, 209-231.

https://doi.org/10.1093/esr/17.3.209

Hansen, M. N., \& Mastekaasa, A. (2006). Social Origins and Academic Performance at University. European Sociological Review, 22, 277-291. https://doi.org/10.1093/esr/jci057

Hurst, A. L. (2018). Classed Outcomes: How Class Differentiates the Careers of Liberal Arts College Graduates in the US. British Journal of Sociology of Education, 39, 1075-1093. https://doi.org/10.1080/01425692.2018.1455495

International Labour Organization (2016). Global Wage Report 2016/17: Wage Inequality in the Workplace. International Labour Office.

https://www.ilo.org/wcmsp5/groups/public/---dgreports/---dcomm/---publ/documents /publication/wcms 537846.pdf

Isopahkala-Bouret, U., Aro, M., \& Ojala, K. (2021). Positional Competition in a Binary System: The Case of Finnish Higher Education. Tertiary Education and Management, 27, 143-159. https://doi.org/10.1007/s11233-021-09070-8

Isopahkala-Bouret, U., Börjesson, M., Beach, D., Haltia, N., Jónasson, J.-T., Jauhiainen, An., Jauhiainen, Ar., Kosunen, S., Nori, H., \& Vabø, A. (2018). Access and stratification in Nordic higher education. A Review of Cross-Cutting Research Themes and Issues. Education Inquiry, 9, 142-154.

https://doi.org/10.1080/20004508.2018.1429769

Jacob, M., Klein, M., \& Iannelli, C. (2015). The Impact of Social Origin on Graduates' Early Occupational Destinations: An Anglo-German Comparison. European Sociological Review, 31, 460-476. https://doi.org/10.1093/esr/jcv006

Kivinen, O., \& Hedman, J. (2016). Suomalaisen korkeakoulutuksen kansainvälinen taso on väitettyä parempi. mahdollisuuksien tasa-arvo ja korkea osaaminen. [The International Level of Finnish Higher Education Is Better than Supposed. Equal Opportunities and High Competence]. Yhteiskuntapolitiikka, 81, 87-96. 
http://urn.fi/URN:NBN:fi-fe201602196554

Kivinen, O., Hedman, J., \& Kaipainen, P. (2012). Koulutusmahdollisuuksien yhdenvertaisuus suomessa. Eriarvoisuuden uudet ja vanhat muodot. [Equality of Schooling Possibilities in Finland. New and Old Modes of Inequality]. Yhteiskuntapolitiikka, 77, 559-566. http://urn.fi/URN:NBN:fi-fe201301021030

Kohvakka, M., Nevala, A., \& Nori, H. (2019). The Changing Meanings of 'Responsible University'. From a Nordic-Keynesian Welfare State to a Schumpeterian Competition State. In M. P. Sørensen, L. Geschwind, J. Kekäle, \& R. Pinheiro (Eds.), The Responsible University. Exploring the Nordic Context and Beyond (pp. 33-60). Palgrave Macmillan. https://doi.org/10.1007/978-3-030-25646-3 2

Kosunen, S., \& Haltia, N. (2018). Valmennuskurssit ja koulutuskuluttajuus [Preparatory Courses and Consumerism in Education]. Sosiologia, 55, 167-183.

Lehmann, W. (2019). Forms of Capital in Working-Class Students' Transition from University to Employment. Journal of Education and Work, 32, 347-359. https://doi.org/10.1080/13639080.2019.1617841

Loewenthal, J., Alexander, P., \& Butt, G. (2019). Fateful Aspects of Aspiration among Graduates in New York and Los Angeles. International Studies in Sociology of Education, 28, 345-361. https://doi.org/10.1080/09620214.2019.1627898

Mikkonen, S., \& Korhonen, V. (2018). Työläistaustaiset yliopisto-opiskelijat ja koulutusmahdollisuuksien tasa-arvo [ Working-Class University Students and the Equality of Educational Opportunities]. Ministry of Education and Culture. http://urn.fi/URN:ISBN:978-952-263-547-1

Nevala, A., \& Nori, H. (2017). Osallisuuden vanhat ja uudet jakolinjat: Yliopisto-opiskelijoiden sosioekonomisen taustan muutokset ja koulutuksellinen tasa-arvo. [Old and New Dividing Lines of Involvement. Changes in the Socio-Economic Background of University Students and Educational Equality]. In A. Toom, M. Rautiainen \& J. Tähtinen (Eds.), Toiveet ja todellisuus-kasvatus osallisuutta ja oppimista rakentamassa. [Hopes and Reality-Education in Building Involvement] (pp. 36-55). Suomen.

Nori, H., Juusola, H., Kohtamäki, V., Lyytinen, A., \& Kivistö, J. (2021). Korkeakoulutuksen saavutettavuus ja tasa-arvo Suomessa ja verrokkimaissa: GATE-hankkeen loppuraportti. [Accessibility and Equality in Higher Education in Finland and Comparative Countries: Final Report of the GATE Project]. Publications of the Government's Analysis, Assessment and Research Activities, Valtioneuvoston kanslia.

http://urn.fi/URN:ISBN:978-952-383-057-8

Nori, H., Peura, M., \& Jauhiainen, A. (2020). From Imposter Syndrome to Heroic Tales: Doctoral Students' Backgrounds, Study Aims, and Experiences. International Journal of Doctoral Studies, 15, 517-539. https://doi.org/10.28945/4637

Nylund, M. Rosvall, P.-Å., Eiríksdóttir, E. Holm, A.-S., Isopahkala-Bouret, U., Niemi, A-M., \& Ragnarsdóttir, G. (2018). The Academic-Vocational Divide in Three Nordic Countries: Implications for Social Class and Gender. Education Inquiry, 9, 97-121. https://doi.org/10.1080/20004508.2018.1424490 https://www.tandfonline.com/doi/full/10.1080/20004508.2018.1424490

OECD (Organisation for Economic Co-Operation and Development) (2019). Education at a Glance 2019: OECD Indicators. OECD Publishing. https://doi.org/10.1787/f8d7880d-en https://www.oecd-ilibrary.org/education/education-at-a-glance-2019 f8d7880d-en

Rivera, L. A. (2011). Ivies, Extracurriculars, and Exclusion: Elite Employers' Use of Educational Credentials. Research in Social Stratification and Mobility, 29, 71-90. 
https://doi.org/10.1016/j.rssm.2010.12.001

Rivera, L. A. (2012). Hiring as Cultural Matching: The Case of Elite Professional Service Firms. American Sociological Review, 77, 999-1022.

https://doi.org/10.1177/0003122412463213

Social Insurance Institution, Finland (2018). Kelan tilastollinen vuosikirja 2017 [Statistical Yearbook of the Social Insurance Institution 2017]. Kela. http://urn.fi/URN:NBN:fi-fe2018120349699

Tholen, G. (2020). Degree Power: Educational Credentialism within Three Skilled Occupations. British Journal of Sociology of Education, 41, 283-298. https://doi.org/10.1080/01425692.2019.1690427

Tholen, G., Brown, P., Power, S., \& Allouch, A. (2013). The Role of Networks and Connections in Educational Elites' Labour Market Entrance. Research in Social Stratification and Mobility, 34, 142-154. https://doi.org/10.1016/j.rssm.2013.10.003

Thomas, L., \& Quinn, J. (2007). First Generation Entry into Higher Education: An International Study. Society for Research into Open University Press \& Open University Press.

Thomsen, J.-P., Bertilsson, E., Dalberg, T., Hedman, J., \& Helland, H. (2017). Higher Education Participation in the Nordic Countries 1985-2010. European Sociological Review, 33, 98-111. https://doi.org/10.1093/esr/jcw051

Torche, F. (2011). Is a College Degree Still a Great Equalizer? Intergenerational Mobility across Levels of Schooling in the United States. American Journal of Sociology, 117, 763-807. https://doi.org/10.1086/661904 